Article

\title{
Synthesis of Perovskite by Solid-Phase Method with Metatitanic Acid and Calcium Carbonate and Its Pigment Properties Investigation
}

\author{
Han Zhang, Sijia Sun, Wei Liu, Hao Ding * and Jianmeng Zhang \\ Beijing Key Laboratory of Materials Utilization of Nonmetallic Minerals and Solid Wastes, National Laboratory \\ of Mineral Materials, School of Materials Science and Technology, China University of Geosciences, \\ Xueyuan Road, Haidian District, Beijing 100083, China; zhanghan0050@163.com (H.Z.); ssjcugb@163.com (S.S.); \\ 2103150001@cugb.edu.cn (W.L.); 2103180006@cugb.edu.cn (J.Z.) \\ * Correspondence: dinghao@cugb.edu.cn; Tel.: +86-010-8232-2982
}

Received: 17 February 2020; Accepted: 23 March 2020; Published: 26 March 2020

\begin{abstract}
Synthetic perovskite powder (SPP) was synthesized by the solid-phase method using metatitanic acid $\left(\mathrm{TiO}_{2} \cdot \mathrm{nH}_{2} \mathrm{O}\right)$ and calcium carbonate $\left(\mathrm{CaCO}_{3}\right)$ as raw materials, and its structure, morphology, pigment properties and application in architectural coatings were studied. When $\mathrm{TiO}_{2} \cdot \mathrm{nH}_{2} \mathrm{O}$ and $\mathrm{CaCO}_{3}$ were mixed and ground at a molar ratio of $\mathrm{TiO}_{2}: \mathrm{CaO}=1: 1$, and then calcined at $900-1100{ }^{\circ} \mathrm{C}$, SPP with a single perovskite phase was obtained. The characterization results displayed that the unit particle size of SPP was 50-150 nm, the aggregate size was 1-2 $\mu \mathrm{m}$, and its particles were well dispersed. The SPP also had a whiteness of $90.5 \%$, and an oil absorption of $35.03 \mathrm{~g} / 100 \mathrm{~g}$. The hiding power of SPP was $24.02 \mathrm{~g} / \mathrm{m}^{2}$, which was $81.6 \%$ of pure $\mathrm{TiO}_{2}$ hiding power $\left(19.60 \mathrm{~g} / \mathrm{m}^{2}\right)$. When adding SPP to prepare a building exterior wall coating, the contrast ratio of the coating film was 0.92 , which met the requirements of the Chinese national standard GB/T 9755-2014 and was equivalent to adding rutile titanium dioxide. Thus, perovskite synthesized from $\mathrm{TiO}_{2} \cdot \mathrm{nH}_{2} \mathrm{O}$ and $\mathrm{CaCO}_{3}$ by the solid-phase method significantly improved the pigment properties of $\mathrm{TiO}_{2}$ in the same proportion.
\end{abstract}

Keywords: metatitanic acid; calcium carbonate; perovskite; pigment; calcination

\section{Introduction}

Perovskite $\left(\mathrm{CaTiO}_{3}\right.$ or $\left.\mathrm{CaO} \cdot \mathrm{TiO}_{2}\right)$ and perovskite structural materials are an important class of oxides with an $\mathrm{ABO}_{3}$-type general formula. The $\mathrm{Ca}$ ion in $\mathrm{CaTiO}_{3}$ corresponds to the $\mathrm{A}$ cation in the general formula, which has a larger ionic radius and is surrounded by 12 oxygen anions to form a coordinated cubic octahedron, while the Ti ion that constitutes a coordinated octahedron with six oxygen anions occupies the B-site. These octahedrons spread into an extended three-dimensional network through corner-sharing. Perovskite has a density of $4.2 \mathrm{~g} / \mathrm{cm}^{3}$, a hardness of 5.5, and a refractive index of 2.34 to 2.38 [1-3]. Generally, $\mathrm{Ca}$ and $\mathrm{Ti}$ in $\mathrm{CaTiO}_{3}$ are respectively replaced by other alkaline earth metal ions and transition metal ions to form perovskite structural materials. $\mathrm{CaTiO}_{3}$ and perovskite structural materials are stable in structure, and have good light absorption and photocatalytic properties, as well as excellent characteristics that can excite carriers and allow them to be separated and transported quickly [4-6]. Because of these features, perovskite materials are widely used in the fields of solar cells, photovoltaic devices, photodetectors and photocatalysis [7-10]. However, researchers have rarely studied perovskite as an inorganic pigment based on its higher optical refractive index or applied the pigment to products such as architectural coatings.

At present, the methods of synthesizing perovskite mainly include the solution cooling method, hydrothermal synthesis method, sol-gel method, and solid-phase sintering method. The solid-phase 
sintering method for synthesizing perovskite, which involves fully mixing raw materials (powder-like), high-temperature calcination and cooling, has obvious advantages, such as a simple and clean process [11-14]. Yet, since the relatively stable crystalline $\mathrm{TiO}_{2}$ (anatase or rutile) is used as the titanium source in this method, the reaction speed is slow and the cost is high [15]. Metatitanic acid is a precursor for the industrial production of $\mathrm{TiO}_{2}$ pigments by the sulfuric acid method, which is mainly composed of aqueous amorphous $\mathrm{TiO}_{2}$. It has the advantages of a large output, a low cost, a high purity and its reaction activity is higher than that of crystalline $\mathrm{TiO}_{2}$ [16-18]. Therefore, using metatitanic acid instead of the crystalline $\mathrm{TiO}_{2}$ as the raw material for the synthesis of perovskite will play a positive role in improving synthesis efficiency, saving energy and reducing costs.

For the above-mentioned background, synthetic perovskite powder (SPP) was herein synthesized by the solid-phase method using metatitanic acid $\left(\mathrm{TiO}_{2} \cdot \mathrm{nH}_{2} \mathrm{O}\right)$ and calcium carbonate $\left(\mathrm{CaCO}_{3}\right)$ as raw materials. We characterized the structure and morphology of SPP and studied its pigment properties and applications in architectural coatings.

\section{Experiment Section}

\subsection{Materials}

The calcium carbonate in the experiment originated from ground calcium carbonate (GCC) produced by an enterprise in Enshi City, Hubei, China. X-ray diffraction (XRD) analysis showed that the GCC sample contained only one phase of calcite, indicating that the purity of the $\mathrm{CaCO}_{3}$ was high. After relevant characterization, we got the following data about the GCC sample: the whiteness was $96.0 \%$, the oil absorption was $14.21 / 100 \mathrm{~g}$, the hiding power was $165.0 \mathrm{~g} / \mathrm{m}^{2}$, the medium diameter (D50) was $6.90 \mu \mathrm{m}$ and the cumulative particle size distribution number of $90 \%$ (D90) was $27.16 \mu \mathrm{m}$. The experimental metatitanic acid $\left(\mathrm{TiO}_{2} \cdot \mathrm{nH}_{2} \mathrm{O}\right)$ is the intermediate product of titanium dioxide produced by the industrial sulfuric acid method, which was provided by Henan Baililin Chemical Industry Co., Ltd. (Henan, China). Its chemical composition was $87.5 \% \mathrm{TiO}_{2}$ and $12.5 \% \mathrm{H}_{2} \mathrm{O}$, of which $\mathrm{TiO}_{2}$ was mainly amorphous, and only a small amount was anatase. $\mathrm{TiO}_{2} \cdot \mathrm{nH}_{2} \mathrm{O}$ had a whiteness of $92.40 \%$, an oil absorption of $40.16 / 100 \mathrm{~g}$, a hiding power of $30.57 \mathrm{~g} / \mathrm{m}^{2}$, and a median diameter (D50) of $0.76 \mu \mathrm{m}$. In addition, the main reagents used in this study were sodium polyacrylate, linseed oil and distilled water.

\subsection{Synthesis of SPP and Preparing Architectural Coatings with SPP}

The solid-phase synthesis of SPP was as follows: (1) GCC and $\mathrm{TiO}_{2} \cdot \mathrm{nH}_{2} \mathrm{O}$ were weighed according to the molar ratio of $\mathrm{CaO}: \mathrm{TiO}_{2}=1: 1$, mixed and added with water to prepare a slurry with a solid content of $30 \%$; (2) The slurry and grinding balls (diameter $1-3 \mathrm{~mm}$, made of mullite) which accounted for three times the weight of the solids in the slurry were ground in a GSDM-3 $1000 \mathrm{~mL}$ superfine stirring mill (Beijing Gosdel \& Technology Co. Ltd., Beijing, China) for $60 \mathrm{~min}$; (3) The ground $\mathrm{CaCO}_{3}-\mathrm{TiO}_{2} \cdot \mathrm{nH}_{2} \mathrm{O}$ slurry was filtered, dried, calcined at a high temperature and scattered to obtain SPP. The calcination in the third step involved putting the ground $\mathrm{CaCO}_{3}-\mathrm{TiO}_{2} \cdot \mathrm{nH}_{2} \mathrm{O}$ into a SX-4-10 box resistance furnace (Taisite Instruments Co., Ltd., Tianjin, China), raising the temperature to the required value at a heating rate of $5{ }^{\circ} \mathrm{C} / \mathrm{min}$, and then preserving it for a certain time. In order to explore the effect of the calcination temperature and time on the phases in SPP, we first calcined the ground $\mathrm{CaCO}_{3}-\mathrm{TiO}_{2} \cdot \mathrm{nH}_{2} \mathrm{O}$ at different temperatures to obtain SPP-W, where $\mathrm{W}$ is the calcination temperature value. Then the ground $\mathrm{CaCO}_{3}-\mathrm{TiO}_{2} \cdot \mathrm{nH}_{2} \mathrm{O}$ was calcined at $900{ }^{\circ} \mathrm{C}$ for different times to obtain SPP-900-T, where $\mathrm{T}$ is the calcination time value. For comparison, pure $\mathrm{TiO}_{2}$ pigments were prepared by directly calcining $\mathrm{TiO}_{2} \cdot \mathrm{nH}_{2} \mathrm{O}$ at $900{ }^{\circ} \mathrm{C}$.

The process of preparing architectural coatings with SPP as pigment was as described in [19]: (1) Raw materials were weighed according to the following coating formulation components and their proportions (mass fraction, $\mathrm{wt} \%$ ): 21 acrylic emulsion (AC-261); 21 water; 0.1 wetting agent; 0.64 dispersant (731A); $0.2 \mathrm{pH}$ regulator; 0.24 defoamer (CF-754); 1.5 film-forming additive (C-12); 0.1 leveling agent (FSN); 0.72 leveling agent (2020); 2.2 thickener (DR-72); 4.8 talcum powder $(23 \mu \mathrm{m})$; 
7 kaolin $(18 \mu \mathrm{m}) ; 5$ utron (a filler); 15 white pigment (SPP, pure $\mathrm{TiO}_{2}$ pigment, commercial titanium dioxide) and 20.5 GCC, total 100. (2) The components above were placed sequentially in a high-speed mixer to prepare the coating.

\subsection{Structure Characterization and Performance of SPP}

The phase components of SPP and other samples were tested and analyzed by XRD, using a D/MAX 2000/PC X-ray powder diffractometer (Rigaku Corporation, Tokyo, Japan) with Cu K $\alpha$ radiation $(\lambda=0.15418 \mathrm{~nm})$ generated at $35 \mathrm{kV}$ and $50 \mathrm{~mA}$. We used a speed of $2 \% / \mathrm{min}$ and a sampling interval of $0.02^{\circ}$ to scan the sample between $10-80^{\circ}$. The structure and morphology of SPP were characterized by S-4800 scanning electron microscopy (SEM, Hitachi Electron Microscopy Company, Tokyo, Japan) with $10 \mathrm{kV}$ acceleration voltage and $14.1 \mathrm{~mm}$ working distance and a Tecnai G2 F20 transmission electron microscope (TEM, FEI Company, The Netherlands) with $200 \mathrm{kV}$ acceleration voltage.

The main pigment performance of SPP was evaluated by the indexes of whiteness, hiding power and oil absorption. Among them, the oil absorption was determined in accordance with the Chinese national standard GB/T 5211.15-2014 (General Methods of Test for Pigments and Extenders-Part 15: Determination of Oil Absorption). The hiding power was measured according to the Chinese national industry standard HG/T 3851-2006 (Covering Power Determination of Dyestuff) [20]. On the basis of the measured hiding power of SPP and pure $\mathrm{TiO}_{2}$ pigments (marked as $\mathrm{C}_{\mathrm{SPP}}$ and $\mathrm{C}_{\mathrm{T}}$ respectively), the relative hiding power of SPP was calculated, that is, the ratio of SPP's hiding power to that of pure $\mathrm{TiO}_{2}\left(\mathrm{R}, \mathrm{R}=100 \% \times \mathrm{C}_{\mathrm{T}} / \mathrm{C}_{\mathrm{SPP}}\right)$. The part whose $\mathrm{R}$ value exceeded the $\mathrm{TiO}_{2}$ content in the SPP $(58.8 \%)$ indicated an improvement in the hiding ability due to the conversion of $\mathrm{TiO}_{2}$ to perovskite $(\mathrm{R}, \mathrm{R}=\mathrm{R}-58.8 \%)$.

The covering performance of architectural coatings prepared by adding SPP and other pigments was characterized by the coating film contrast ratio. A coating film with a thickness of $80 \mu \mathrm{m}$ was prepared on a black and white plate using a BB-type wire rod applicator for coating materials. After being air-dried, the reflectance of the coating film in the black and white areas (recorded as $F_{b}$ and $F_{w}$ ) was measured with a C84-III reflectance tester (Shanghai Modern Environment Engineering Technique Co., Ltd., Shanghai, China) and converted into a contrast ratio $\left(\mathrm{F}_{\mathrm{b}} / \mathrm{F}_{\mathrm{w}}\right)$.

\section{Results and Discussion}

\subsection{Effect of Calcination Temperature and Time on the Phase of SPP Particles}

The XRD patterns of the ground $\mathrm{CaCO}_{3}-\mathrm{TiO}_{2} \cdot \mathrm{nH}_{2} \mathrm{O}$ and its products calcined at different temperatures (SPP-W) for $30 \mathrm{~min}$ are shown in Figure 1a. In the ground $\mathrm{CaCO}_{3}-\mathrm{TiO}_{2} \cdot \mathrm{nH}_{2} \mathrm{O}$, the diffraction peaks of calcite and anatase appear, reflecting the characteristics of anatase in $\mathrm{TiO}_{2} \cdot \mathrm{nH}_{2} \mathrm{O}$ and $\mathrm{CaCO}_{3}$ (JCPDS No. 05-0586) in the GCC. The phase compositions of SPP-500 and SPP-600 are the same as that of the ground $\mathrm{CaCO}_{3}-\mathrm{TiO}_{2} \cdot \mathrm{nH}_{2} \mathrm{O}$, which indicated that calcination at a lower temperature cannot generate a new phase. Increasing the temperature to $700{ }^{\circ} \mathrm{C}$, in addition to calcite and anatase, causes a weak diffraction peak of perovskite to appear in the XRD pattern. This may be due to the reaction of calcite and anatase synthesizing perovskite at the interface between them. Meanwhile, the SPP- 800 particles were composed of perovskite, anatase and $\mathrm{CaO}$, and the diffraction peak of calcite in the pattern disappeared, showing that the decomposition reaction of $\mathrm{CaCO}_{3}$ occurred (the decomposition products were $\mathrm{CaO}$ and $\mathrm{CO}_{2}$ ). As the temperature further increased to $900-1100{ }^{\circ} \mathrm{C}$, both the anatase and $\mathrm{CaO}$ in the XRD patterns of the calcined products disappeared. The phases of SPP-900, 1000 and 1100 were completely composed of perovskite (JCPDS No. 22-0153) and the diffraction peaks were significantly enhanced compared with the calcined products below $900{ }^{\circ} \mathrm{C}$, which demonstrated that we synthesized the SPP with a single perovskite phase at $900-1100^{\circ} \mathrm{C}$.

The XRD patterns of the ground $\mathrm{CaCO}_{3}-\mathrm{TiO}_{2} \cdot \mathrm{nH}_{2} \mathrm{O}$ calcined at $900{ }^{\circ} \mathrm{C}$ for different times (SPP-900-T) are displayed in Figure 1b. Although the heating time was increased from 30 to $120 \mathrm{~min}$, the obtained products were all single phases of perovskite, and increasing the calcination time had 
no effect on the phase composition of SPP-900. Considering this comprehensively, we selected a calcination temperature of $900{ }^{\circ} \mathrm{C}$ and a time of $30 \mathrm{~min}$ as the optimal conditions for the synthesis of SPP.
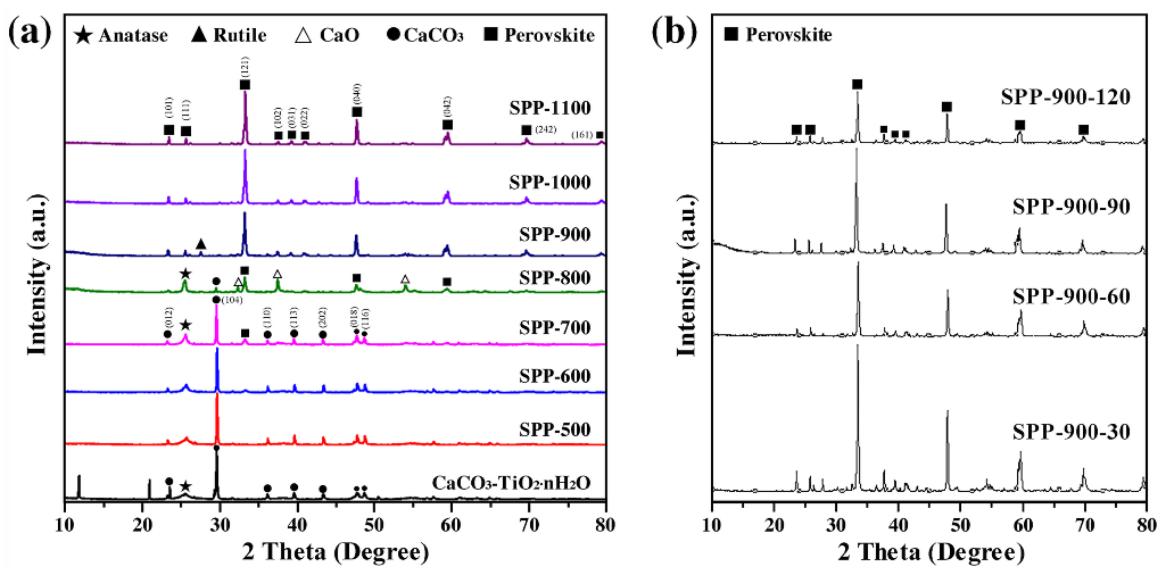

Figure 1. XRD patterns of (a) $\mathrm{CaCO}_{3}-\mathrm{TiO}_{2} \cdot \mathrm{nH}_{2} \mathrm{O}$ calcined at different temperatures and (b) for different times (SPP-900).

The transformation of $\mathrm{CaCO}_{3}-\mathrm{TiO}_{2} \cdot \mathrm{nH}_{2} \mathrm{O}$ phases, along with the calcination temperature and the process of finally synthesizing the perovskite, are exhibited in Figure 2. This diagram shows that when the calcination temperature was raised to $700^{\circ} \mathrm{C}$, a small amount of perovskite was generated due to the reaction between $\mathrm{CaCO}_{3}$ and $\mathrm{TiO}_{2}$. When the temperature continued to increase, $\mathrm{CaCO}_{3}$ decomposed to form $\mathrm{CaO}$, and the final perovskite was formed by the reaction of $\mathrm{CaO}$ and $\mathrm{TiO}_{2}$. The reaction equations at different temperatures are provided as follows:

$$
\begin{gathered}
700^{\circ} \mathrm{C}: \mathrm{TiO}_{2}+\mathrm{CaCO}_{3} \rightarrow \mathrm{CaTiO}_{3}+\mathrm{CO}_{2} \uparrow \\
800^{\circ} \mathrm{C}: \mathrm{CaCO}_{3} \rightarrow \mathrm{CaO}+\mathrm{CO}_{2} \uparrow \\
900^{\circ} \mathrm{C}: \mathrm{TiO}_{2}+\mathrm{CaO} \rightarrow \mathrm{CaTiO}_{3}
\end{gathered}
$$

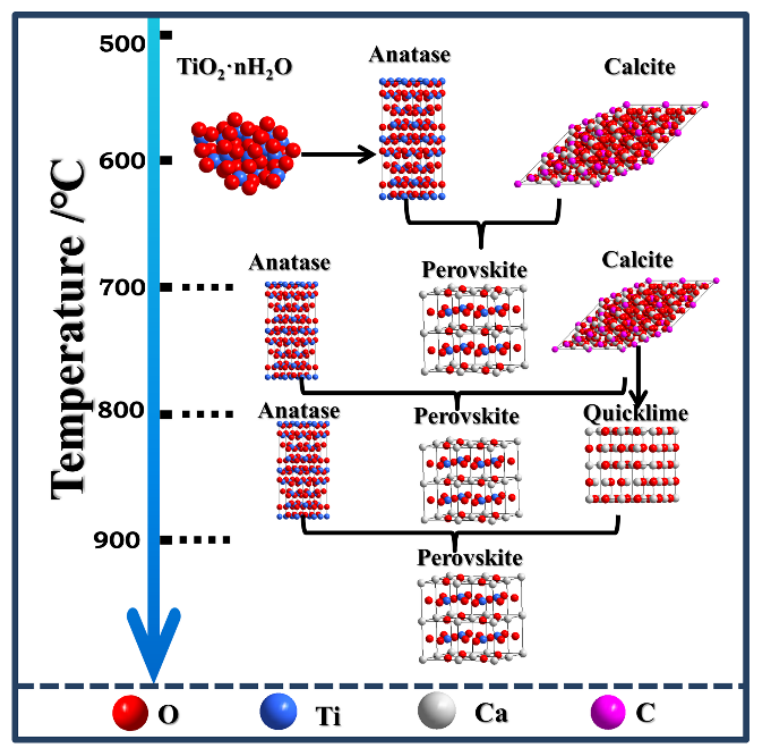

Figure 2. Schematic diagram of perovskite phase transformations during the synthesis of SPP. 
Figure 3 shows the TG/DSC curves of $\mathrm{CaCO}_{3}$ and $\mathrm{TiO}_{2} \cdot \mathrm{nH}_{2} \mathrm{O}$. In Figure $3 \mathrm{a}$, the endothermic peak and $44.3 \%$ weight loss of $\mathrm{CaCO}_{3}$ appeared at $794{ }^{\circ} \mathrm{C}$, corresponding to the phenomenon of $\mathrm{CO}_{2}$ release due to its decomposition. It can be observed from Figure $3 \mathrm{~b}$ that $\mathrm{TiO}_{2} \cdot \mathrm{nH}_{2} \mathrm{O}$ began its endothermic peak from $289^{\circ} \mathrm{C}$ and gradually lost weight between $550-800{ }^{\circ} \mathrm{C}$, which is attributed to the loss of structured water in $\mathrm{TiO}_{2} \cdot \mathrm{nH}_{2} \mathrm{O}$. The exothermic peak at about $800{ }^{\circ} \mathrm{C}$ indicates a phase transition of $\mathrm{TiO}_{2}$ from anatase to rutile. These features are consistent with the XRD results in Figure 1.
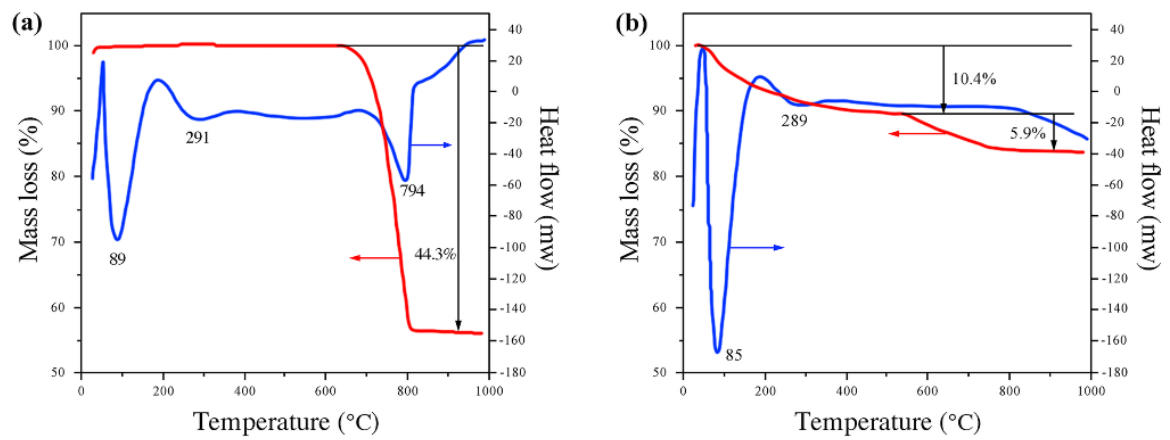

Figure 3. TG/DSC curves of (a) $\mathrm{CaCO}_{3}$ and (b) $\mathrm{TiO}_{2} \cdot \mathrm{nH}_{2} \mathrm{O}$.

\subsection{Effect of Calcination Temperature on the Morphology of SPP Particles}

Figure 4 shows SEM images of the ground $\mathrm{CaCO}_{3}-\mathrm{TiO}_{2} \cdot \mathrm{nH}_{2} \mathrm{O}$ calcined at different temperatures for $30 \mathrm{~min}$. In Figure $4 \mathrm{a}$, the $\mathrm{CaCO}_{3}-\mathrm{TiO}_{2} \cdot \mathrm{nH}_{2} \mathrm{O}$ without calcination consisted of two kinds of particles with different morphologies and sizes. The larger particles with a particle size of 3-6 $\mu \mathrm{m}$ and an irregular block shape were $\mathrm{CaCO}_{3}$, while the smaller particles with a size of $0.5-1 \mathrm{~m}$ and a uniform distribution were $\mathrm{TiO}_{2} \cdot \mathrm{nH}_{2} \mathrm{O}$, exhibiting the composition characteristics of $\mathrm{GCC}$ and $\mathrm{TiO}_{2} \cdot \mathrm{nH}_{2} \mathrm{O}$ in the raw materials. The morphology of $\mathrm{CaCO}_{3}-\mathrm{TiO}_{2} \cdot \mathrm{nH}_{2} \mathrm{O}$ particles calcined at 500,600 , and $700{ }^{\circ} \mathrm{C}$ in Figure $4 \mathrm{~b}-\mathrm{d}$ is basically the same as the raw materials that were not calcined in Figure $4 \mathrm{a}$, revealing that there was no formation of a new phase at a low calcination temperature. Unlike the above samples, although the size of the large particles in SPP-800 remained unchanged, their edges and corners mostly disappeared, and the appearance became mellowed (Figure 4e). This phenomenon was attributed to the thermal decomposition of $\mathrm{CaCO}_{3}$ in the raw materials to generate $\mathrm{CaO}$ at this temperature. It can be seen from Figure $4 \mathrm{f}-\mathrm{h}$ that the particle morphology of SPP-900, SPP-1000 and SPP-1100 was granular and long columnar, with the size of about 1-2 $\mu \mathrm{m}$. In these three samples, the SPP-900 particles had better dispersibility, while the SPP-1000 and SPP-1100 particles agglomerated with each other (the latter had a stronger aggregation behavior.) This is the manifestation of $\mathrm{CaCO}_{3}-\mathrm{TiO}_{2} \cdot \mathrm{nH}_{2} \mathrm{O}$ calcined at $900-1100{ }^{\circ} \mathrm{C}$ to form perovskite. The conclusions obtained from the SEM image analysis in this section were consistent with the above $\mathrm{XRD}$ results.

Figure $4 \mathrm{i}$ is the TEM image of SPP- $900\left(\mathrm{CaCO}_{3}-\mathrm{TiO}_{2} \cdot \mathrm{nH}_{2} \mathrm{O}\right.$ calcined at $\left.900{ }^{\circ} \mathrm{C}\right)$ synthesized by the solid-phase method. It can clearly be observed that the perovskite unit particles were ellipsoidal, and their size was about $50-150 \mathrm{~nm}$. The Figure $4 \mathrm{i}$ inset is the HRTEM image of SPP-900, displaying its clear lattice fringes. We measured an interval scale of $0.2701 \mathrm{~nm}$, which corresponded to the interplanar spacing of the (121) plane of the perovskite crystals, further confirming the result of XRD that SPP was composed of a perovskite phase [21]. 


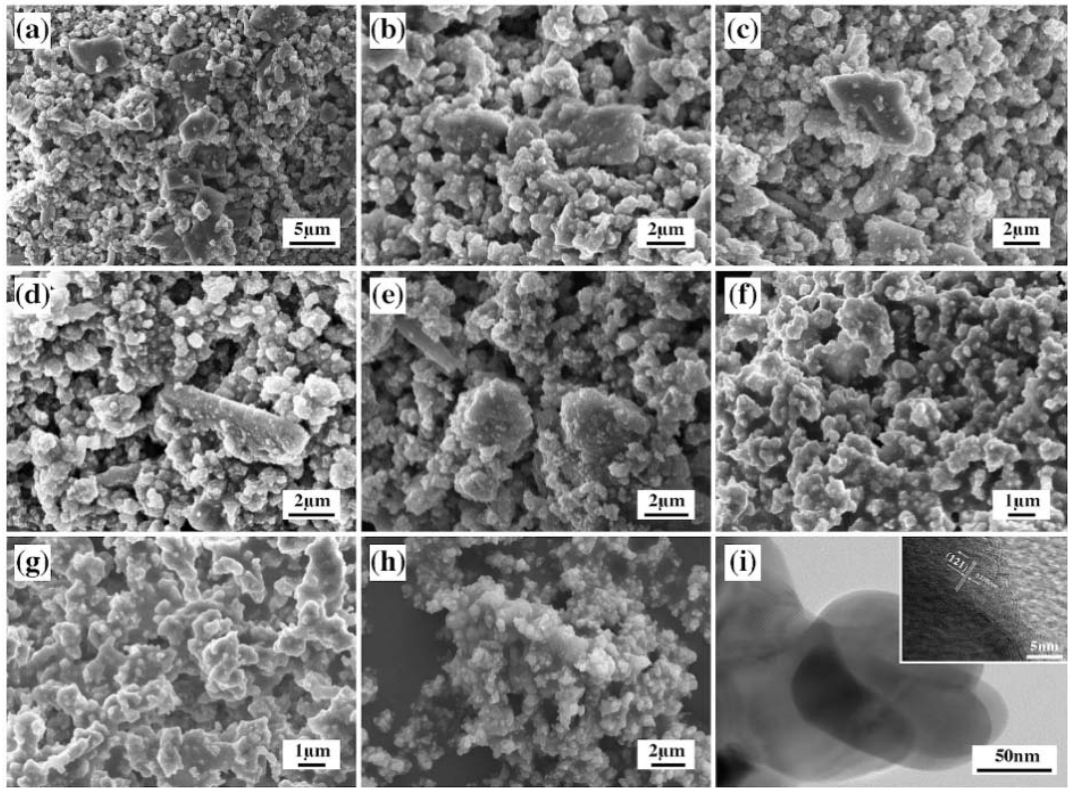

Figure 4. SEM images of (a) $\mathrm{CaCO}_{3}-\mathrm{TiO}_{2} \cdot \mathrm{nH}_{2} \mathrm{O}$ and $(\mathbf{b}-\mathbf{h})$ its calcined products at different temperatures. (b) $500{ }^{\circ} \mathrm{C}$; (c) $600{ }^{\circ} \mathrm{C}$; (d) $700{ }^{\circ} \mathrm{C}$; (e) $800{ }^{\circ} \mathrm{C}$; (f) $900{ }^{\circ} \mathrm{C}$; (g) $1000{ }^{\circ} \mathrm{C}$; (h) $1100{ }^{\circ} \mathrm{C}$. (i) TEM and HRTEM (inset) images of SPP-900.

\subsection{Pigment Properties of SPP Particles}

Figure 5 shows the hiding power and oil absorption of $\mathrm{CaCO}_{3}-\mathrm{TiO}_{2} \cdot \mathrm{nH}_{2} \mathrm{O}$ calcined at different temperatures. The hiding power of SPP particles decreased from 38 to $24 \mathrm{~g} / \mathrm{m}^{2}$ by degrees with the increase in calcination temperature (from 25 to $900{ }^{\circ} \mathrm{C}$ ), which means that its hiding performance gradually increased. When the temperature was higher than $700^{\circ} \mathrm{C}$, the magnitude of the enhancement became significantly larger, which was apparently caused by the presence of perovskite in the calcined products and its growing content. When the temperature was raised to 1000 and $1100{ }^{\circ} \mathrm{C}$, we discovered that the hiding power of the SPP drops to about $22.5 \mathrm{~g} / \mathrm{m}^{2}$, that is, the hiding performance continues to increase and reaches a stable value, which should be the result of the SPP having only a perovskite phase and an increased degree of crystallization. Figure 5 also describes the tendency of the SPP's oil absorption to gradually decrease with the increase in the calcination temperature, where the oil absorption of the SPP at a temperature higher than $900{ }^{\circ} \mathrm{C}$ was less than $35 \mathrm{~g} / 100 \mathrm{~g}$.

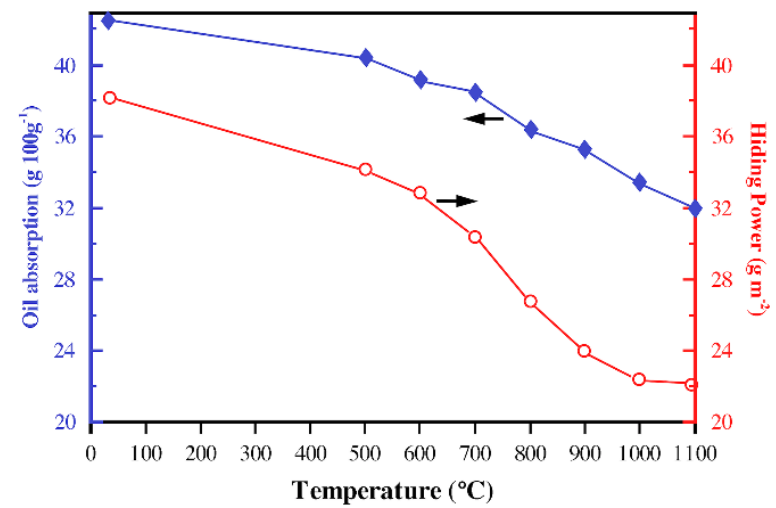

Figure 5. Oil absorption (rhombus) and hiding power (hollow circle) of $\mathrm{CaCO}_{3}-\mathrm{TiO}_{2} \cdot \mathrm{nH}_{2} \mathrm{O}$ calcined at different temperatures.

The comparison of the pigment performance between SPP-900, pure $\mathrm{TiO}_{2}$ pigment $\left(\mathrm{TiO}_{2} \cdot \mathrm{nH}_{2} \mathrm{O}\right.$ calcined at $900{ }^{\circ} \mathrm{C}$ ) and raw GCC is shown in Table 1 . Clearly, the hiding power values of the raw 
GCC and pure $\mathrm{TiO}_{2}$ pigments are $165.00 \mathrm{~g} / \mathrm{m}^{2}$ and $19.60 \mathrm{~g} / \mathrm{m}^{2}$, respectively, indicating that the GCC had no hiding ability while the pure $\mathrm{TiO}_{2}$ pigment had a strong hiding ability. The hiding power of the SPP synthesized by the solid-phase method was $24.02 \mathrm{~g} / \mathrm{m}^{2}$, which was close to that of the pure $\mathrm{TiO}_{2}$ pigment and much stronger than the experimental data of the raw GCC. An in-depth analysis of these data shows that the hiding power of SPP reached $81.6 \%$ ( $\mathrm{R}$, relative hiding power) of the pure $\mathrm{TiO}_{2}$ pigment, which was $22.8 \%$ higher than the proportion of $\mathrm{TiO}_{2}$ contained in perovskite $(58.8 \%)$. The results show that the synthesis of perovskite by using $\mathrm{CaCO}_{3}$ and $\mathrm{TiO}_{2} \cdot \mathrm{nH}_{2} \mathrm{O}$ as raw materials significantly improved the hiding performance of $\mathrm{TiO}_{2}$, which was the reason why SPP had the same hiding performance as the pure $\mathrm{TiO}_{2}$ pigment. Besides, the oil absorption of SPP was close to that of $\mathrm{TiO}_{2}$ pigments (values were 35.03 and $33.26 \mathrm{~g} / 100 \mathrm{~g}$, respectively). Therefore, SPP is considered to have comprehensive properties comparable to pure $\mathrm{TiO}_{2}$ pigments.

Table 1. Pigment performance comparison of $\mathrm{SPP}$, pure $\mathrm{TiO}_{2}$ pigments and raw GCC.

\begin{tabular}{cccccc}
\hline Samples & $\begin{array}{c}\text { Oil Absorption/ } \\
\mathbf{g} \cdot \mathbf{1 0 0} \mathbf{~ g}^{\mathbf{- 1}}\end{array}$ & Whiteness/\% & $\begin{array}{c}\text { Hiding } \\
\text { Power/g. } \mathbf{m}^{-\mathbf{2}}\end{array}$ & $\begin{array}{c}\text { Relative Hiding } \\
\text { Power (R)/\% }\end{array}$ & $\begin{array}{c}\mathbf{( R}=\mathbf{R}- \\
\mathbf{5 8 . 8}) / \%\end{array}$ \\
\hline $\mathrm{SPP}$ & 35.03 & 90.5 & 24.02 & 81.60 & 22.80 \\
Pure TiO 2 & 33.26 & 87.8 & 19.60 & 100 & - \\
Raw GCC & 14.21 & 96.2 & 165.00 & 11.88 & - \\
\hline
\end{tabular}

\subsection{Coating Performance with SPP as a Pigment}

Based on the formula and steps in Section 2.2, we obtained the contrast ratio of architectural coating films prepared with SPP, pure $\mathrm{TiO}_{2}$ pigment and commercial titanium dioxide (rutile) as white pigments. The coating film contrast ratios of these three coatings all exceeded 0.90 , meeting the requirements of the Chinese National Standard GB/T 9755-2014 [22]. The contrast ratio of SPP's coating film was 0.92 , which was slightly lower than that of rutile titanium dioxide coating (0.93), but larger than the value of pure $\mathrm{TiO}_{2}$ pigment (0.91), demonstrating that the SPP had reached the level of titanium dioxide with the same proportion, so it can be used as a pigment for architectural coatings. The contrast ratio is an index reflecting the opacity of the coating film, which mainly depends on the properties of the pigment in it, including oil absorption and hiding power. The contrast ratio of the coating with SPP was equivalent to the coating with pure $\mathrm{TiO}_{2}$ pigment or rutile titanium dioxide, and this confirmed that SPP had the same performance as pure $\mathrm{TiO}_{2}$ pigment and rutile titanium dioxide.

\section{Conclusions}

Using metatitanic acid $\left(\mathrm{TiO}_{2} \cdot \mathrm{nH}_{2} \mathrm{O}\right)$ and calcium carbonate $\left(\mathrm{CaCO}_{3}\right)$ as raw materials, synthetic perovskite powder (SPP) with a single perovskite phase was synthesized by the solid-phase method at a calcination temperature of $900-1100{ }^{\circ} \mathrm{C}$. The process of generating perovskite with an increasing calcination temperature involved a small amount of perovskite initially formed by the reaction of $\mathrm{CaCO}_{3}$ and $\mathrm{TiO}_{2}$, and after the decomposition of $\mathrm{CaCO}_{3}$ into $\mathrm{CaO}$ and $\mathrm{CO}_{2}$, the subsequent perovskite was formed by the reaction between $\mathrm{CaO}$ and $\mathrm{TiO}_{2}$. Particles of SPP, with a unit particle size of $50-150 \mathrm{~nm}$ and an aggregate size of $1-2 \mu \mathrm{m}$, were well dispersed. The whiteness of the SPP was $90.5 \%$.

The synthesized SPP had a pigment performance equivalent to that of pure $\mathrm{TiO}_{2}$. Its oil absorption was $35.03 \mathrm{~g} / 100 \mathrm{~g}$. Its hiding power was $24.02 \mathrm{~g} / \mathrm{m}^{2}$ and this value reached $81.6 \%$ of $\mathrm{TiO}_{2}$ pigment, which is $22.8 \%$ higher than the proportion of $\mathrm{TiO}_{2}$ in perovskite. Adding SPP to architectural coatings has a coating film contrast ratio of 0.92 , which matches the use of rutile titanium dioxide, and meets the Chinese National Standard (GB/T 9755-2014).

Author Contributions: Conceptualization, H.D. and H.Z.; Methodology, H.D. and H.Z.; software, J.Z.; validation, H.D., H.Z. and S.S.; formal analysis, S.S.; investigation, H.Z. and W.L.; resources, H.D.; data curation, H.Z. and W.L.; writing—original draft preparation, H.D., H.Z. and S.S.; writing—review and editing, H.Z.; supervision, H.D.; project administration, H.D.; funding acquisition, H.D. All authors have read and agreed to the published version of the manuscript. 
Funding: This research was funded by the Fundamental Research Funds for the Central Universities of China (Grant No. 292018301).

Conflicts of Interest: The authors declare no conflict of interest.

\section{References}

1. Pena, M.A.; Fierro, J.L.G. Chemical Structures and Performance of Perovskite Oxides. Chem. Rev. 2001, 101, 1981-2017. [CrossRef] [PubMed]

2. Wong, Y.J.; Hassan, J.; Hashim, M. Dielectric properties, impedance analysis and modulus behavior of $\mathrm{CaTiO}_{3}$ ceramic prepared by solid state reaction. J. Alloys Compd. 2013, 571, 138-144. [CrossRef]

3. Schouwink, P.; Ley, M.B.; Tissot, A.; Hagemann, H.; Jensen, T.R.; Smrcok, L.; Cerny, R. Structure and properties of complex hydride perovskite materials. Nat. Commun. 2014, 5, 5706. [CrossRef] [PubMed]

4. Liu, Z.; Paterson, A.R.; Wu, H.; Gao, P.; Ren, W.; Ye, Z.-G. Synthesis, structure and piezo-/ferroelectric properties of a novel bismuth-containing ternary complex perovskite solid solution. J. Mater. Chem. C 2017, 5, 3916-3923. [CrossRef]

5. Xu, X.; Su, C.; Zhou, W.; Zhu, Y.; Chen, Y.; Shao, Z. Co-doping Strategy for Developing Perovskite Oxides as Highly Efficient Electrocatalysts for Oxygen Evolution Reaction. Adv. Sci. (Weinh) 2016, 3, 1500187. [CrossRef] [PubMed]

6. Zhang, L.; Nie, Y.; Hu, C.; Qu, J. Enhanced Fenton degradation of Rhodamine B over nanoscaled Cu-doped $\mathrm{LaTiO}_{3}$ perovskite. Appl. Catal. B Environ. 2012, 125, 418-424. [CrossRef]

7. Correa-Baena, J.P.; Saliba, M.; Buonassisi, T.; Grätzel, M.; Abate, A.; Tress, W.; Hagfeldt, A. Promises and challenges of perovskite solar cells. Science 2017, 358, 739-744. [CrossRef] [PubMed]

8. Gao, R.; Jain, A.C.P.; Pandya, S.; Dong, Y.; Yuan, Y.; Zhou, H.; Dedon, L.R.; Thoreton, V.; Saremi, S.; Xu, R.; et al. Designing Optimal Perovskite Structure for High Ionic Conduction. Adv. Mater. 2020, 32, e1905178. [CrossRef] [PubMed]

9. Bin Adnan, M.A.; Arifin, K.; Minggu, L.J.; Kassim, M.B. Titanate-based perovskites for photochemical and photoelectrochemical water splitting applications: A review. Int. J. Hydrogen Energy 2018, 43, 23209-23220. [CrossRef]

10. Grabowska, E. Selected perovskite oxides: Characterization, preparation and photocatalytic properties-A review. Appl. Catal. B Environ. 2016, 186, 97-126. [CrossRef]

11. Dong, W.; Song, B.; Meng, W.; Zhao, G.; Han, G. A simple solvothermal process to synthesize $\mathrm{CaTiO}_{3}$ microspheres and its photocatalytic properties. Appl. Surf. Sci. 2015, 349, 272-278. [CrossRef]

12. Dubey, A.K.; Tripathi, G.; Basu, B. Characterization of hydroxyapatite-perovskite $\left(\mathrm{CaTiO}_{3}\right)$ composites: Phase evaluation and cellular response. J. Biomed. Mater. Res. B Appl. Biomater. 2010, 95, 320-329. [CrossRef] [PubMed]

13. Holliday, S.; Stanishevsky, A. Crystallization of $\mathrm{CaTiO}_{3}$ by sol-gel synthesis and rapid thermal processing. Surf. Coat. Technol. 2004, 188-189, 741-744. [CrossRef]

14. Orihashi, T.; Adachi, S. Synthesis condition and structural/luminescent properties of $\mathrm{CaTiO}_{3}: \mathrm{Eu}^{3+} \mathrm{red}$ phosphor. J. Alloys Compd. 2015, 646, 1116-1123. [CrossRef]

15. Evans, I.R.; Howard, J.A.K.; Sreckovic, T.; Ristic, M.M. Variable temperature in situ X-ray diffraction study of mechanically activated synthesis of calcium titanate, $\mathrm{CaTiO}_{3}$. Mater. Res. Bull. 2003, 38, 1203-1213. [CrossRef]

16. Wang, Y.; Li, J.; Wang, L.; Xue, T.; Qi, T. Preparation of Rutile Titanium Dioxide White Pigment via Doping and Calcination of Metatitanic Acid Obtained by the NaOH Molten Salt Method. Ind. Eng. Chem. Res. 2010, 49, 7693-7696. [CrossRef]

17. Gesenhues, U. Calcination of Metatitanic Acid to Titanium Dioxide White Pigments. Chem. Eng. Technol. 2001, 24, 685-694. [CrossRef]

18. Yahui, L.; Fancheng, M.; Fuqiang, F.; Weijing, W.; Jinglong, C.; Tao, Q. Preparation of rutile titanium dioxide pigment from low-grade titanium slag pretreated by the $\mathrm{NaOH}$ molten salt method. Dyes Pigment. 2016, 125, 384-391. [CrossRef]

19. Sun, S.; Ding, H.; Hou, X. Preparation of $\mathrm{CaCO}_{3}-\mathrm{TiO}_{2}$ Composite Particles and Their Pigment Properties. Materials 2018, 11, 1131. [CrossRef] [PubMed] 
20. HG/T 3851-2006. Covering Power Determination of Dyestuff; National Development and Reform Commission: Beijing, China, 2006.

21. Huang, Y.-J.; Tsai, M.-C.; Chiu, H.-T.; Sheu, H.-S.; Lee, C.-Y. Artificial Synthesis of Platelet-Like Kassite and Its Transformation to $\mathrm{CaTiO}_{3}$. Cryst. Growth Des. 2010, 10, 1221-1225. [CrossRef]

22. GB/T 9755-2014. Synthetic Resin Emulsion Coatings for Exterior Wall; Standards Press of China: Beijing, China, 2014. 